\title{
THE SPANISH-AMERICAN WAR OF 1898: QUERIES INTO THE RELATIONSHIP BETWEEN THE PRESS, PUBLIC OPINION AND POLITICS
}

\author{
SYLVLA L. HILTON \\ Universidad Complutense de Madrid
}

\section{(Resumen)}

En vista de la importancia que se concede en muchas versiones del conflicto hispano-americano de 1898 al papel de la opinión pública, este artículo analiza las divergencias interpretativas en la reciente historiografía española en torno a las relaciones entre opinión pública, prensa y la toma de decisiones políticas conducentes a la guerra, al objeto de reflexionar sobre el ejercicio del poder político y la atribución de responsabilidades históricas.

When Spain declared war against the United States in April of 1898, Prime Minister Sagasta justified his decision by saying: "The government has done no more than follow the imperious current of opinion." Similarly Senator Lodge affirmed: "It was this public sentiment that drove Congress forward to meet the popular will, which members and Senators very well knew could be fulfilled by war and in no other way." "

These statements immediately pose problems of grave and permanent historical importance concerning the relationship between public opinion and political decisions, the ways and means by which public opinion is formed and makes itself heard, the role of political leadership in democratic regimes, and the ways in which the idea of popular pressure is used by politicians and historians alike to explain or justify government actions.

Almost all versions of the Spanish-American conflict of 1898 stress the importance of public opinion and the press, and their connection with the political decisions leading to the war. Robles $(1991,33)$ for example, states that "public opinion forced the government to accept the war", thus accepting Sagasta's explanation of his actions, but Salas Larrazábal $(1988,596)$ flatly rejects Sagasta's attempt to shirk his responsibility during the crisis of 1898 , maintaining instead that political leaders have a duty to inform and channel public opinion, at the same time as they must resist popular pressure in favour of politically unsound decisions. These same issues are cunningly dissected by Louis Pérez (1989), in connection with the way in which the sinking of the

1. Lodge, Henry Cabot. The War with Spain. New York, 1899, p. 32. 
Maine was received by American public opinion and has since been narrated in American histories of the war of 1898.

The growing influence of the press and public opinion in contemporary politics would appear to be beyond all doubt, but there does seem to be considerable confusion both as to the nature and the efficacy of the connections.

One view, for example, holds that in this aspect the American and Spanish cases were dissimilar, suggesting that while the American press contributed to form popular ideology in 1898, by contrast, the Spanish press exerted less influence and was little more than an imperfect transmitter of the dominant ideology of the ruling classes. ${ }^{2}$ The present article proposes to review this subject as reflected in recent historiography published in Spain.

The press, seeking to establish and/or augment its own power and importance, has frequently attributed to itself roles as representative and spokesman for the public at large. It would seem evident that this identification between press and general public opinion is subject to some doubt, if not outright rejection. However, many historians seem to accept it uncritically, using the terms "press" and "public opinion" indiscriminately as synonyms, and presenting the opinions of minority interest groups, political parties, one newspaper or even one individual journalist or contributor, as indicative of generalized opinion.

On the eve of the war with the United States, the notion that the American "yellow" press (particularly William Randolph Hearst's New York Joumal and Joseph Pulitzer's New York World) deliberately used false, malicious, irresponsible and sensationalist articles, solely with a view to increasing sales, by engaging and inflaming public opinion, is a commonplace in traditional interpretations of the crisis. ${ }^{3}$

Indeed, most Spanish authors continue to lay at least part of the blame for McKinley's final decision to intervene directly in Cuba on the "yellow" press. Even though the denunciation of "Spanish barbarism", resulting from the hardships inflicted on civilian population in Weyler's concentration camps, was to a certain extent justified and inspired by sincere humanitarian principles, " there is a general consensus among Spanish historians that the American press was manipulative and unfair in its reporting of Cuban issues.

The "yellow" press in particular is characterized as immoral, hypocritical, and provocative for condemning Weyler's methods, for ridiculing or criticizing all things Spanish, for prematurely announcing the failure of the new Cuban autonomous regime

2. Elorza, 1988, 327-8; Robles, 1991, XII, XV.

3. Classical examples in American historiography are Marcus M. Wilkerson: Public Opinion and the Spanish-American War. A Study in War Propaganda. Louisiana State University Press, Baton Rouge, 1932, repr. Russell \& Russell, New York, 1967; Joseph E. Wissan: The Cuban Crisis As Reflected in the New York Press (1895-1898). Columbia University Press, New York, 1934, repr. Octagon Books, New York, 1965.

4. Serrano, 1984, 28, and Elorza, 1988, 372-3, are careful to point out this fact. 
inaugurated in January of 1898, for maliciously reporting the affair of Spanish embassador Dupuy's indiscrete private letter (which contained unflattering remarks about McKinley), and for accusing Spain of sinking the Maine. ${ }^{s}$

The Dupuy letter scandal, in early February, is seen by many as plainly manifesting Hearst's bad faith and the McKinley administration's exploitation of this type of journalism, not just because of the questionable methods and timing, but, more pointedly, because the principle of freedom of expression in private correspondence was defended only by the diplomatic corps in Washington, and not by American journalists themselves or by any official spokesman from the White House. ${ }^{\circ}$

The definitive example of the close relationship between sensationalist journalism, popular belligerency, and political decisions must still be the reactions to the sinking of the Maine. Whether the press reflected or whipped up popular pressure in favour of a war with Spain, and both pushed the government along that path, or whether the government exploited and encouraged the various manifestations of popular bellicosity in order to justify the final decision to intervene in Cuba, (Serrano, 1984, 31-32) practically all versions of the crisis coincide in that events after the explosion of the American warship led inexorably to war, and an aura of inevitability floats over the vast majority of narrations. ${ }^{7}$

Not all American newspapers ran sensationalist and belligerent articles merely to increase their sales, (Bolado, 1991, 51) but even Midwestern papers predisposed American public opinion towards American intervention and war with Spain, by dedicating a lot of attention to the Cuban conflict, by favouring Cuban rebel propaganda, by insistently repeating and linking humanitarian and social Darwinist ideas with the Monroe Doctrine, Manifest Destiny, and Anglo-Saxonism, by harping on American economic and strategic interests in the Caribbean, and in general by offering an unfavourable image of Spain. ${ }^{8}$

In general, the American press is deemed to have helped to create ample public support for a policy of imperialist expansion. However, the relation between press and public opinion remains unclear. It is recognized that the United States had gradually

5. Bermeosolo, 1962, 226-33; Alonso, 1983, 132; Serrano, 1984, 31-3; Sevilla, 1986, 481; Morales Padrón, 1987, 125-6; Companys, 1987, 468-71; 1988, 330-6, and 1989, 2-4, 20, 37-42, 139-40; Calleja, 1990, 164; Allende, 1990, 68; Bolado, 1991, 49-53, 107, 114-8; Navarro, 1992, 368.

6. Serrano, 1984, 33; Companys, 1987, 467-74, and 1989, 3-4; Bolado, 1991, $106-10$.

7. In this view, Spanish authors agree with the interpretation dominant in American historiography. Pérez, 1989, 295-302, 317. American press coverage of this incident is considered to have been highly irresponsible by Bermeosolo, 1962, 228-30; Sevilla, 1986, 485; Companys, 1989, 4, 20, 37-42; Calleja, 1990, 171-3; Bolado, 1991, 118; Navarro, 1992, 368.

8. González López-Briones, 1990, makes these points in her analysis of six Indiana newspapers. 
been developing economic and strategic interests in the Caribbean and the Pacific since the end of the War of Secession (if not long before that), and that political and ideological factors meant that these interests had become more intense since the mid-eighties. This does not mean, however, that there was any strong popular support for expansionism, and here historiographical interpretations vary. Some authors contend that there was, indeed, such support in the 1890s,' but others, by contrast, hold that the American people were to a large extent deceived and mobilized by the "yellow" press. ${ }^{10}$

Faced with the outbreak of the Cuban war of independence in 1895, a simple view seems to suggest that American press and/or public opinion were almost entirely sympathetic to the Cuban rebels and to the idea of American intervention from the start $^{11}$.

A more careful approach reveals, however, that in the early stages of the Cuban war, American public opinion was divided. Inevitably many sympathized with the Cuban struggle for independence, associating it with the Angloamerican rebellion of 1776, but more conservative sectors frowned upon the wholescale destruction of private property by the rebels, they disliked what they saw as a predominantly Negro rebellion reminiscent of the Haitian revolution, and they doubted that Cuban revolutionary leaders would be able to establish a stable government. (Navarro, 1992, 368) Nonetheless, little mention is made of the existence of any antiimperialist or antiinterventionist opinion in the United States. ${ }^{12}$

On the whole, then, the American people are far too simplistically portrayed in many Spanish versions as being ignorant about other cultures and nations, as being naive, uncritical and credulous, and as being unable or unwilling to distinguish or condemn journalistic frauds, even when blatant lies were occasionally denounced by a rival newspaper. ${ }^{13}$

However, this unsubstantiated view of American public opinion is not a failing exclusive to Spanish historiography. In many American versions "the onset of the war is portrayed as a function of an aroused public opinion, which, as commonly acknowledged, need not be rational, and therefore need not be explained." (Pérez, 1989, 300)

Equally problematic is the follow-up notion that this press campaign and/or public opinion effectively influenced Congress and the McKinley administration in their perception and handling of the crisis and American policy.

9. Allende, 1990, 67-8; Calleja, 1990, 193; Elizalde, 1992, 196.

10. Bermeosolo, 1962, 226; Companys, 1987, 468-9, 474, and 1989, 36, 42, 83; Togores, $1990,1,660$.

11. Bermeosolo, 1962, 226; Companys, 1987, 468-9, 474, and 1989, 36, 42, 83; Togores, $1990, \mathrm{I}, 660$.

12. Allende, $1990,61,69-70$, does so in a too-obvious attempt to be even-handed.

13. Implicit in many Spanish works, this view is explicit in Companys, 1988, 327, 332-9, and $1989,2-4,36,142-3$. 
Many authors see McKinley as a weak and indecisive politician, easily swayed (to the point of being driven to war against his wish, in some versions) by the press and public opinion. ${ }^{14}$ This view is analogous to the interpretations that stress large-scale, long-term developments in economic structures, as factors determining American imperialism in the $1890 \mathrm{~s}$, in that either way, the role of presidential leadership is diminished. ${ }^{15}$

Others, by contrast, envisage McKinley's administration as simply disguising their true determination to intervene in Cuba. ${ }^{16}$ The relationship between presidential actions and the press, in this assessment, varies from suggestions that the government simply followed their own premeditated policy plans, and took advantage of sensationalist and Jingoistic journalism when it coincided with their own views, ${ }^{17}$ to affirmations that the McKinley team not only were not influenced in their policy plans by public opinion, but, in fact, were largely responsible themselves for the growing popular bellicosity in the United States. ${ }^{18}$

Similarly, a great deal of attention has been paid to the relationship between public opinion and political decisions in Spain in 1898. Few would doubt the importance of the rising tide of nationalist and imperialist modes of thought in the case of the United States, but a relevant question arises concerning the degree to which the imperialist discourse of the late nineteenth century penetrated in Spanish opinion.

14. Alonso, 1983, 132-3; Robles, 1986, 261; Níguez, 1987, 88; Companys, 1987, 466-9, 474, and 1989, 29-30, 42, 46-48, 86, 105, 109-10, 116, 140; Calleja, 1990, 184-5, 193; Allende, 1990, 66-8; Togores, 1990, I, 660; Olivié, 1992, 135-7. Again, this is a common interpretation in American historiography. See Johnson, 1986, 56, and Pérez, 1989, 306-12.

15. Johnson, 1986, 55-6, argues strongly in favour of a more balanced approach which would recognize the historical relevance of individual actions.

16. Pabón, 1963, 168; Serrano, 1984, 30-33; Andrés, 1985, 20; Sevilla, 1986, 477-8; Companys, 1987, 480, and 1989, 135-6; Salas Larrazábal, 1988, 594-5; Allende, 1990, 66-8; Bolado, 1991, 57; Olivié, 1992, 135-7. This view also predominates in Cuban historiography. For American support of the portrayal of McKinley as designer of his own expansionist foreign policy, see for example Leech, Margaret. In the Days of McKinley. Harper, New York, 1959, Morgan, H. Wayne. William McKinley and His America. Syracuse University Press, Syracuse, 1963, Foner, Philip S. The Spanish-Cuban-American War and the Birth of American Imperialism. Monthly Review Press, New York, 1972, specially I, 287-300, and Johnson, 1986, 59-74.

17. Sevilla, 1986, 485; Companys, 1988, 335.

18. Companys, $1989,83,140,143$. It is not clear whether this last interpretation is simply an addition to this author's earlier version, or whether it is offered as a new reconsideration of McKinley's determined leadership. In any case, the confusion concerning the relationship between public opinion and McKinley's actions is also discernible in American historiography. See discussion by Foner, 1972, I, 281, 287-300. 
(Rivadulla, 1989, 189) Despite the unpopular image of an army used by the government to repress regionalist and working class interests, some authors contend that popular, patriotic bellicosity did in fact exist in connection with overseas territories, not only in 1898 , but also during the conflict with Germany over possession of the Caroline Islands in 1885, and during the conflict with Morocco in 1893 . $^{19}$

The general perception that American interference in the Cuban war, and overall conduct throughout the crisis, were immoral and profoundly offensive to Spanish national honour found expression in the generalized depiction of the United States as a pig in Spanish newspapers and in diverse popular protests, ${ }^{\infty}$ and at the same time provoked many popular demonstrations in towns throughout Spain, often fervently patriotic and anti-Yankee, sometimes violent. ${ }^{21}$ It is even affirmed that the Spanish patriotic response to imminent war against the United States in 1898 was almost unanimous, (the socialists, followers of Pi y Margall and the Stock Exchange being the few exceptions).(Robles, 1986, 281, and 1991, 110)

A different interpretation, however, is that the popular classes were deeply frustrated and demoralized by the long Cuban wars. Discontent with the social injustice of the recruitment system, the high death rate resulting not only (or even primarily) from military actions, but from lack of food supplies, tropical diseases, and deficient sanitary and medical attention, had undermined popular interest in conserving Cuba. Against this background of disillusionment and suffering, popular patriotic demonstrations were encouraged by the government in 1895 , whereas later agitation was impulsed by the republican opposition, leading to questions concerning the evolution of popular opinion throughout the crisis. (Serrano, 1984, 90-7) Mothers of new recruits for Cuba demonstrated their sorrow and protest in several Spanish towns, and it eventually became politically advisable to forbid the families of departing recruits to accompany them on train stations and docks. (Fernández Muñiz, 1988, 557) Finally, the number of men called to military service in Cuba that obtained exemption through fraudulent means, or that went missing or quickly deserted increased between 1895 and 1898, offering another angle on popular opinion about the war. (Serrano, 1982, 253-78, and 1984, 94-7)

In this view, by early 1897 many in Spain were apparently resigned to the idea that defeat by the American colossus, though painful, would at least be honourable, and would definitively end the Cuban war. ${ }^{22}$ The idea that large sectors of Spanish society, in fact, wanted peace at any price, but did not manifest this opinion because they did not want to appear antipatriotic, has been put forward by several authors. ${ }^{23}$

19. Hernández Sandoica, 1982, 616-8, 643-4; Alonso, 1983, 130; Elorza, 1988, 353-5; Núñez, 1989, 232; Schulze, 1989, 271-2, 280; Elizalde, 1992, 53-4.

20. Elorza, 1988, 354-5, 373-4; Bolado, 1991, 166-7, 187, 193.

21. Serrano, 1981, 439-50, and 1984, 32-3, 84-5, 90-3; Elorza, 1988, 355.

22. Elorza, 1988, 327, 360, 366, 374, 386.

23. Serrano, 1984, 46, 131; Andrés, 1985, 20; Sevilla, 1986, 491-2; Lasa, 1991, 130-1; Bolado, 1991, 93-4. 
The niceties of analyzing popular opinion are well illustrated by the violent demonstrations which took place in Málaga in response to McKinley's message to Congress of 11th April. Initially characterized as a burst of student and urban, middle class patriotic protest directed against the American Consulate, the mob soon took on a very different meaning, when popular elements began to assault property and symbols of the established social and political order in Spain itself. In this process, the patriotic and anti-Yankee message faded considerably. (Arcas, 1989, 289-92)

On the other hand, it is interesting to see that Catalonian and Basque businessmen supported the policies of pacification and retention of Cuba with a view to protecting their commercial privileges in the island, while Catalonian and Basque regionalists opposed both the Cuban and the American war, perceived as further expression of central government oppression of their respective nationalities. ${ }^{24}$ This divergence between the propertied elites and the popular classes of the peripheral regions of Spain also emerges in the Andalusian town of Malaga. (Arcas, 1989, 283-9)

Indeed, it is becoming increasingly evident and significant that the Spanish press in 1898 was a means of expression not solely of the predominant ideology of colonialist nationalism (characterized by patriotic exaltation, equally belligerent regarding Cuban independence and American intervention), but also of the profound social tension which converted the colonial conflict into a general crisis in which the very essence of Spanish nationalism was questioned. ${ }^{25}$

Nevertheless, the Spanish press and public opinion are often deemed to have exerted great pressure on the government in 1898, severely limiting the range of acceptable political options. Most Spanish authors stress the fact that the Spanish press vehemently condemned American aid to the Cuban rebels, and on the eve of the war of 1898 became overwhelmingly patriotic, irrational, derisive of American military power, and irresponsibly optimistic about the victorious outcome of an armed conflict with the United States. ${ }^{26}$

In the domestic context of Spanish political rivalries, American interference concerning Spain's handling of the Cuban rebellion induced liberal opposition newspapers to accuse the Cánovas government of spinelessly yielding to Yankee pressures, and this naturally led the conservative press to sternly deny any intention of permitting the United States to dictate government measures. Cuba was not considered a colony but an integral part of the Spanish monarchy, and therefore the predominant

24. Elorza, 1988, 328-29, 355; Serrano, 1984, 47-64, 118-27, and 1988, 388-90; Lasa, 1991, 109-47.

25. Serrano, 1982, 271-2, and 1988, 391; Fernández Muñiz, 1988, 554-7.

26. Alonso, 1983, 130; Serrano, 1984, 71-3, 84-85; Sevilla, 1986, 470, 473, 482-3, 487, 490-91, 497, 513-14; Ñíguez, 1987, 88; Elorza, 1988, 354-5, 374, 384; Salas Larrazábal, 1988, 596, 606; Companys, 1989, 96; Cervera, 1990, 151; Rodríguez González, 1990, I, 633, 643, 652; Bordeje, 1990, 153-4; Téllez, 1990, 41-3; Togores, 1990, I, 667; Bolado, 1991, 115-9, 126, 137, 141, 161; Robles, 1991, 34-119. 
ideology prohibited not only the sale of the island to the United States, but also the concession of independence, at least as long as the rebel army remained in existence. Therefore there was little press support for any practical, conciliatory policies, and as American interference became increasingly difficult to tolerate in the early months of 1898 , the great majority of Spanish newspapers whipped themselves up into a frenzy of patriotic, belligerent indignation, leaving the government with very little room for manoevre. ${ }^{n}$

Spanish military rhetoric was steeped in rigid patriotic belligerency and, together with the Spanish army's history of interference in government affairs, represented a serious obstacle to Sagasta's desperate efforts to avoid a war against the United States. ${ }^{28}$ Military officers saw the colonies not only as an integral part of Spanish national territory, which they were honour-bound to defend, but also as places in which professional careers could be promoted. ${ }^{*}$ For their part, the ultra-conservative Carlists were prone to express imperialist belligerency, and clamorously supported general Weyler's actions in Cuba. (Serrano, 1984, 75-9)

The Catholic Church and Catholic workers' organizations also played an important role in support of the war, with a view to maintaining the existing colonial order and opposing the advance of Protestant and Masonic power. (Serrano, 1984, 48, 64-70) The archbishop of Seville, Marcelo Spinola, made no attempt to curb his intensely patriotic, bellicose, anti-Liberal, anti-Masonic, anti-Protestant and anti-American opinions. (Ruiz Sánchez, 1988) The bishops of Barcelona, Salamanca and Malaga, together with the cardinal-archbishop of Valencia and the archbishop of Madrid-Alcalá were likewise staunch supporters of the war. ${ }^{30}$

For their part, the left-wing Republicans, with the notable exception of pacifist Pi y Margall, apparently thought that disaster was imminent, and that, if the monarchy collapsed in the ensuing institutional crisis, they would be better placed to take over the government if they could be seen to have adopted patriotic stances in the face of Cuban insurgency and American intervention. ${ }^{31}$ The inference from this explanation must be that the party's interest in the downfall of the government and possibly of the monarchy itself took precedence over the foreseeable material and human costs of a war.

27. Elorza, 1988, 327, 374, 383; Arcas, 1989, 283-4; Bolado, 1991, 61-3; Robles, 1991, XI.

28. Robles, 1986, 269-71, and 1991, XII, 27, 91, 145; Serrano, 1988, 389; Companys, 1989, 88-9.

29. Manuel Espadas Burgos: "Le facteur outre-mer dans la formation du militaire espagnol." Mélanges de la Casa de Velázquez. Boccard, Paris, 1978, t. XIV, and Serrano, 1984, 48; Alvarez, 1990, 77; Bordeje, 1990, 154.

30. Serrano, 1984, 67-9; Arcas, 1989, 284.

31. Sevilla, 1986, 483, 491; Serrano, 1984, 79-89, 112-8, and 1988, 388-90; Arcas, 1989, 291; Bolado, 1991, 88. 
Only El Socialista and El Nuevo Régimen steadfastly expressed pacifist opinions throughout the crisis. In fact, the Spanish Socialist Party garnered considerable political credit in the post-war years for its opposition to the war. Internal divisions plagued the Party at the start of the Cuban rebellion, but by late 1897 Spanish socialists were again united and able to conduct a campaign designed to reflect and cultivate popular hostility to the war. ${ }^{32}$

Finally, anarchist newspapers, which represented an unstructured minority opinion in Spain, were beset by serious ideological ambivalencies regarding the Cuban war of 1895 . On the one hand, Spanish anarchists felt that they should not support a rebellion whose only aim was political independence, because it had no revolutionary content as regards the liberation of the Cuban proletariate. The belligerent patriotism of the ruling classes, whether Spanish or Cuban, held no promise of improvement for the working class. Nevertheless, some anarchists evidently sympathized with the principle of armed rebellion, and gradually came to express the hope that Cuban separatism would evolve into a full-scale social revolution. ${ }^{33}$

The press was not alone in the expression of patriotic values. Short stories and, in particular, theatre plays and zarzuelas (operettas), written or staged during the crisis, also contained these themes. However, most were penned by second-rate authors and none achieved a massive success, giving rise to at least the suspicion that leading intellectuals and creative authors were reluctant to support the patriotic ideas prevalent in the press, and also that the Spanish public was not overwhelmingly moved by the rhetoric of the stage or the press. ${ }^{34}$

Surprisingly, and despite all the accumulated evidence of American expansionist aspirations in the Caribbean and the Pacific, several authors contend that the Spanish government and the Liberal press were slow to become fully aware of the threat, not just to Cuba but to Puerto Rico and the Philippines. ${ }^{35}$ One must therefore pose the question of whether these interpretations are in fact taking government declarations and public attitudes at their face value, without making the obvious critical appraisal that it was in the government's interest not to express its worst fears, in order to guard against the warnings from becoming self-fulfilling, to avoid giving cause for popular unrest, and also to appear to be in all respects the unsuspecting victim of American greed and bad faith.

When Sagasta finally made the decision to declare war on the United States on 24th April, it is often explained that the government believed that neither public opinion nor the military and naval hierarchies would have accepted any other decision. However,

32. Serrano, 1979, 1984, 99-105, and 1988, 390-1; Elorza, 1988, 340, 353, 361, 373; Fernández Muñiz, 1988, 557-8; Bolado, 1991, 75-7, 93-4, 120-1, 127, 137-8, 141-2; Robles, 1991, 92, 113.

33. Núñez, 1991; Serrano, 1984, 105-12, and 1988, 390-1.

34. Serrano, 1984, 72-4; Sevilla, 1986, 490.

35. Sevilla, 1986, 475\%5, 484; Salas Larrazábal, 1988, 608. 
a darker interpretation raises the suspicion that Sagasta's government only pretended to believe in the belligerent mood of the Spanish people in defense of Cuba, in order to justify the decision to go to war. This decision was taken in fact, according to this view, in the conviction that Spain would be defeated, solely to save the Liberal Party and perhaps the monarchy from being ousted, either by a military coup or a social revolution. ${ }^{36}$

Some authors even go so far as to suggest that Sagasta was relieved by American intervention because Spain could not win the war against the rebels, and a quick defeat by overwhelmingly superior American forces would afford the government an honourable escape from the Cuban war without putting the throne at risk. ${ }^{37}$

The historical problems surrounding Sagasta's decision to declare war and its justification in the name of public opinion by the government itself, by contemporary commentators, and often by historians, give a different meaning, although equally pertinent, to Perez's reflexions on McKinley's decision to wage war against Spain: "Attributed as it is to the will of the people, war serves as a metaphor for triumph of popular democracy. ... elected officials are obliged to acquiesce, perhaps against their better judgment if not against their will", and so, "political leaders are presumed innocent of willing war and, by implication, absolved of responsibility for war." (Pérez, 1989, 305, 319) Sagasta's and. McKinley's decisions led to events which had profoundly different consequences for the nations involved, but both chose to absolve themselves of historical responsibility by appearing to bow to popular pressure.

In order to explain the press's insistence on Spanish naval superiority and on the general military incapacity of the United States, on the eve of the war, opinions vary. One theory is that the press deliberately misled the public into thinking that Spain would win an immediate victory. ${ }^{38}$ Another theory is that the press itself was misinformed about respective Spanish and American naval strengths, and some authors suggest that the increasing complexity of criteria for the classification of war vessels made it difficult to determine with any accuracy real fighting power. ${ }^{3}$ The inference from this point

36. Andrés, 1985, 24; Salas Larrazábal, 1988, 596, 606; Serrano, 1988, 388; Torre, 1988 Inglaterra, 67-125; Rivadulla, 1989, 188, 192; Cervera, 1990, 151; Togores, 1990, I, 667; Bolado, 1991, 127-5; Fernández Aponte, 1992, 43; Companys, 1987, 478, and 1989, 88; Téllez, 1990, 41, 44.

37. Serrano, 1984, 43-6. This author states that there was a deliberate plan to go to war in order to lose it (author's emphasis); Serrano, 1988, 388; Torre, 1988 Inglaterra, 67-8.

38. This accusation is commonly, and perhaps understandably, found in the works written in the immediate aftermath of the war by Spanish politicians and naval officers. See Téllez, 1990, 41- 44; Cerezo, 1977, 274. Sevilla, 1986, 497. Nevertheless Serrano, 1984, 71-2, supports this view.

39. Juan B. Robert: "La prensa periódica y la Marina en 1898." $R G M$, mayo 1948, 579;

Cerezo, 1977, 266-73; Cervera, 1990, 55; Bordeje, 1990, 154. Téllez, 1992, 58-65. 
is that if official Navy reports reflected this difficulty, the press cannot be entirely maligned for misrepresenting Spanish naval strength. However, this can be disputed on the grounds that the Spanish press had consistently dedicated much attention to naval policy and affairs long before 1898 , adopting a uniformly critical attitude of government measures, that complete and correct information was available to the press from the best sources, and that these sources revealed Spanish naval inferiority. ${ }^{40}$

The belligerency of the press in 1898 and its incoherency on naval matters, must, then, be put down to some other factor. On the one hand, the inability of journalists to correctly analyze available information might have induced the sincere misconception that Spanish and American naval forces were reasonably balanced, simply because they were so dissimilar that contemporaries had some difficulty in discerning which type of navy would prove to be superior, the large, armoured, slower American battleships, or the smaller, lighter, faster Spanish armed cruisers and torpedo ships. ${ }^{41}$

On the other hand, misguided patriotism, which could not contemplate surrender without a fight, is also put forward as an explanation why informed people might deliberately misrepresent the known facts. High ranking, politically influential, and well informed naval officers, for example, maintained optimistic views of Spanish naval power in comparison with American forces, by which attitude they must be held largely responsible for misleading the government, the press, and in the last analysis, public opinion. ${ }^{42}$

In conclusion, then, recent trends in works published in Spain show on the one hand a great interest in analyzing a wide range of sources which are presumed to be relevant to the study of public opinion. Newspapers and other publications of different ideological affiliations, creative literature, popular songs, public entertainment, teachings of the Church, opinions or attitudes expressed through popular demonstrations in the street, meetings and associations, or resistence to military service, have all been examined, though these avenues of enquiry have by no means been exhausted. Private correspondence and personal diaries of the period have not yet been brought to bear with a view to adding nuances to these analyses.

On the other hand, these contributions represent a growing awareness of the complex, many-layered character of public opinion in Spanish society, (though this awareness is strangely lacking when referring to American society), but there is still a tendency to avoid defining the concept of "public opinion", and therefore to deal superficially with the relationship between public opinion and the press. Not enough attention has been paid to questions concerning the extent to which public opinion might be simply reflected in, and/or deliberately mobilized by, the press, or to the variability even in the short term of popular attitudes.

40. Vega, 1990, 106; Rodríguez González, 1990, I, 642-3, 652.

41. Rodríguez González, 1990, I, 634-7, 643-4, 652; Téllez, 1992, 59, 65-6.

42. Rodríguez González, 1990, 1, 638-41. 
It is increasingly evident that, even taking into account the variety of periodical literature, the press does not cover the entire ideological spectrum of Spanish society at the end of the century. Public opinion and popular sentiments were not only fragmented, nuanced and variable but, to a large extent, often not fully or truly reflected in the press. This argument is of theoretical value insomuch as it tends to question or even reject the view that public opinion can be held, in the last analysis, responsible for policy decisions of the government. If the conclusion is reached that public opinion was not freely and clearly expressed (by the press or in any other way), its relevance as a factor of historical causation must be greatly reduced, or at the very least carefully qualified.

At the same time, ruling elites (and specifically political leaders) and the press (not as spokesman for "the people", but as identifiable representatives of specific interest groups) must be apportioned their fair share of historical responsibility for political decisions, in order to balance the insidious tendency to make public opinion (and by extension, "the people" in general) diffusely responsible for government decisions and actions which were ideologically dubious and/or caused much unnecessary distress. 


\section{BIBLIOGRAPHY}

ALONSO BAQUER, Miguel. "La guerra hispanoamericana de 1898 y sus efectos sobre las instituciones militares españolas." $R H M I, \mathrm{XXVII} / 54,1983$, pp. 127-151.

ALVAREZ ARENAS, Eliseo. "Lo naval en el Noventa y Ocho." La Marina ante el 98. II. Gënesis, 1990, II, pp. 71-108.

ALLENDE SALAZAR Y VALDES, José Manuel. "La clase política norteamericana ante la guerra del 98." La marina ante el 98. II. Génesis, 1990, II, pp. 59-70.

ANDRES GALLEGO, José. Regeneracionismo y crisis del 98. Cuadernos de Historia 16, n. 30, Madrid, 1985.

ARCAS CUBERO, Fernando. "Málaga en el 98. Repercusiones sociales de la guerra hispano-cubano-americana." $B A, 12,1989$, pp. 281- 298.

BERMEOSOLO, Francisco. "La opinión pública norteamericana y la guerra de los Estados Unidos contra España." REP, 123, mayo- junio 1962, pp. 219-233.

BOLADO ARGUELLO, Nieves. La independencia de Cuba y la prensa: apuntes para la historia. Torrelavega (Bilbao), Ayuntamiento de Torrelavega, Artes Gráficas Quinzaños, 1991.

CALLEJA LEAL, Guillermo G. "La voladura del Maine." RHMI, XXXIV/69, 1990, 161-196.

CEREZO MARTINEZ, Ricardo. "Tercer decenio de la "Revista" (1897- 1906). Hacia el Desastre." RGM, 192, 1977, pp. 259-277.

CER VERA PERY, José. "Marinos españoles en su protagonismo histórico." La Marina ante el 98. Antecedentes de un conflicto. Madrid, 1990, pp. 49-74.

COMPANYS MONCLUS, Julián. "La carta de Dupuy de Lôme." $B R A H, 184 / 3$, septiembre-diciembre 1987, pp. 465-481.

...-.. "Los orígenes de la prensa "amarilla" y su relación con la insurrección cubana de 1895." BRAH, 185/2, mayo-agosto 1988 , pp. 327-346.

De la explosión del Maine a la nuptura de relaciones diplomáticas entre Estados Unidos y España (1898). Lleida, Universitat de Barcelona, 1989. 
ELIZALDE PEREZ-GRUESO, María Dolores. España en el Pacífico. La colonia de las Islas Carolinas, 1885-1899. Madrid, Consejo Superior de Investigaciones Científicas, 1992.

ELORZA, Antonio. "Con la marcha de Cádiz: imágenes españolas de la guerra de independencia cubana." EHS, 44-47, 1988, pp. 327- 386.

FERNANDEZ APONTE, Irene. El cambio de soberania en Puerto Rico. Otro '98. Madrid, Editorial Mapfre, S.A., 1992.

FERNANDEZ MUÑIZ, Aurea Matilde. "Las quintas: sistema de reclutamiento: explotación para unos y negocio para otros (1868- 98)." EHS, 44-47, 1988, pp. 553-559.

FRY, Joseph A. "William Mckinley and the Coming of the Spanish- American War: A Study of Besmirching and Redemption of an Historical Image." Diplomatic History, III, 1979, pp. 77-79.

GONZALEZ LOPEZ-BRIONES, Carmen. "The Indiana Press and the Coming of the Spanish-American War, 1895-1898." ATL, 12/1, 1990, pp. 165-176.

HERNANDEZ SANDOICA, Elena. Pensamiento burgués y problemas coloniales en la España de la Restauración. Tesis doctoral. Madrid, Universidad Complutense, 1982.

JOHNSON, Lyman L. "Presidential Leadership in Foreign Affairs: McKinley's Role in the Spanish-American War." $B A M, 28 / 36,1986$, pp. 55-74.

La Marina ante el 98. Antecedentes de un conflicto. $V$ Jornadas de Historia Maritima. Madrid, Cuadernos Monográficos del Instituto de Historia y Cultura Naval, n. 8, 1990.

La Marina ante el 98. Génesis y desarrollo de un conflicto. VI Jomadas de Historia Maritima. Madrid, Cuadernos Monográficos del Instituto de Historia y Cultura Naval, n. 11, 1990, 2 vols.

LASA A YESTARAN, Eugenio. "La burguesía catalana hace un siglo: de la conquista del mercado colonial a la pérdida del Imperio." TRI, 18, noviembre 1991, pp. 109-148.

LEFEBER, Walter. "That "Splendid Little War" in Historical Perspective." Texas Quarterly, XI, Winter 1968, pp. 89-98.

MORALES PADRON, Francisco. Historia de unas relaciones dificiles: EE.UU. América española. Sevilla, Universidad de Sevilla, 1987. 
NAVARRO GARCLA, Luis. La independencia de Cuba. Madrid, Editorial Mapfre, S.A., 1992.

NUÑEZ FLORENCIO, Rafael. "El presupuesto de la paz: una polémica entre civiles y militares en la España finisecular." HIS, XLIV/171, enero-abril 1989, pp. 197-234.

...-.. "Los anarquistas españoles y americanos ante la guerra de Cuba." HIS, 51/179, septiembre-diciembre 1991, pp. 1077-1092.

ÑIGUEZ BERNAL, Antonio. "Las relaciones políticas, económicas y culturales entre España y los Estados Unidos en los siglos XIX y XX." QC, 12, 1987, pp. 71-134.

OLIVIE, Fernando. La herencia de un imperio roto. Madrid, Editorial Mapfre, S.A., 1992.

PABON, Jesús. El 98, acontecimiento internacional. Madrid, Ministerio de Asuntos Exteriores, 1952, repr. in Días de Ayer. Barcelona, Alpha, 1963, pp. 139-195.

PEREZ, Louis. "The Meaning of the Maine: Causation and the Historiography of the Spanish-American War." Pacific Historical Review, 58/3, August 1989, 293-322.

RIVADULLA BARRIENTOS, Daniel. "El "98" español y sus fuentes: los fondos sobre Filipinas del Archivo General del Palacio Real (Madrid)." Extremo Oriente ibérico. (Actas del primer simposium intemacional: El Extremo Oriente Ibérico, Madrid, 7-10 noviembre 1988). Investigaciones históricas, metodologia y estado de la cuestión. Madrid, Consejo Superior de Investigaciones Científicas, 1989, pp. 183-202.

ROBLES MUÑOZ, Cristóbal. "1898: la batalla por la paz. La mediación de León XIII entre España y Estados Unidos." RI, 46/177, enero-junio 1986, pp. 247-296.

-..-. 1898: Diplomacia y opinión. Madrid, Consejo Superior de Investigaciones Científicas, 1991.

RODRIGUEZ GONZALEZ, Agustín R. "Balances navales, estrategias y decisiones políticas en la guerra de 1898." Estudios históricos. Homenaje a los profesores José Maria Jover y Vicente Palacio Atard. Madrid, Universidad Complutense, Departamento de Historia Contemporánea, 1990, I, pp. 633-653.

RUIZ SANCHEZ, José Leonardo. "La mitra sevillana y el desastre del 98: el patriotismo de don Marcelo Spínola." Temas de Historia Militar. Segundo congreso de Historia Militar, Zaragoza, 1988. Madrid, Servicio de Publicaciones del Estado Mayor del Ejército, 1988, III, pp. 491-505. 
SALAS LARRAZABAL, Ramón. "Las últimas guerras coloniales." Temas de Historia Militar. Segundo Congreso de Historia Militar, Zaragoza, 1988. Madrid, Servicio de Publicaciones del Estado Mayor del Ejército, 1988, I, pp. 569-612.

SCHULZE, Ingrid. "El papel de la prensa española en el conflicto de las Islas Carolinas." BRAH, CLXXXVI, Cuad. II, mayo-agosto 1989, pp. 267-302.

SERRANO, Carlos. "El PSOE y la guerra de Cuba (1895-1898)." EHS, 8-9, enero-junio 1979, pp. 287-310.

-..... "Guerra y crisis social: los motines de Mayo del 98." Estudios de Historia de España. (Homenaje a M. Tuñón de Lara). Universidad Menéndez Pelayo, Madrid, 1981, vol. 1, pp. 439-450.

...... "Prófugos y desertores en la guerra de Cuba." EHS, 22-23, julio-diciembre 1982, pp. 253-278.

Final del Imperio. España, 1895-1898. Madrid, Siglo XXI, 1984.

--... "1898: España en cuestión." EHS, 44-47, 1988, pp. 387-393.

SEVILLA Y SOLER, Rosario. "La intervención norteamericana en Cuba y la opinión pública andaluza." $A E A, 43,1986$, pp. 469-516.

TELLEZ MOLINA, Antonio. "La Marina de Guerra española frente al desastre del 98: una aproximación al testimonio de sus combatientes." $R H N, 8 / 30,1990$, pp. 39-50.

TOGORES SANCHEZ, Luis Eugenio. "España y la expansión de los EE.UU. en el Pacífico. (De la guerra hispano-americana de 1898 y la pérdida de Filipinas, al pleito por Sibutó y Cagayán de Joló)." Estudios históricos. Homenaje a los profesores José María Jover y Vicente Palacio Atard. Madrid, Universidad Complutense, Departamento de Historia Contemporánea, 1990, I, pp. 655-676.

TORRE DEL RIO, Rosario de la. "La prensa madrileña y el discurso de Lord Salisbury sobre las "naciones moribundas" (Londres, Albert Hall, 4 mayo 1898)." CHMC, VI, 1985, pp. 163-180.

Inglaterra y España en 1898. Madrid, EUDEMA, Ediciones de la Universidad Complutense de Madrid, 1988.

VEGA BLASCO, Antonio de la. "Programas y efectivos navales españoles y norteamericanos (1865-1898)." La marina ante el 98. Antecedentes, 1990, pp. 77-108. 


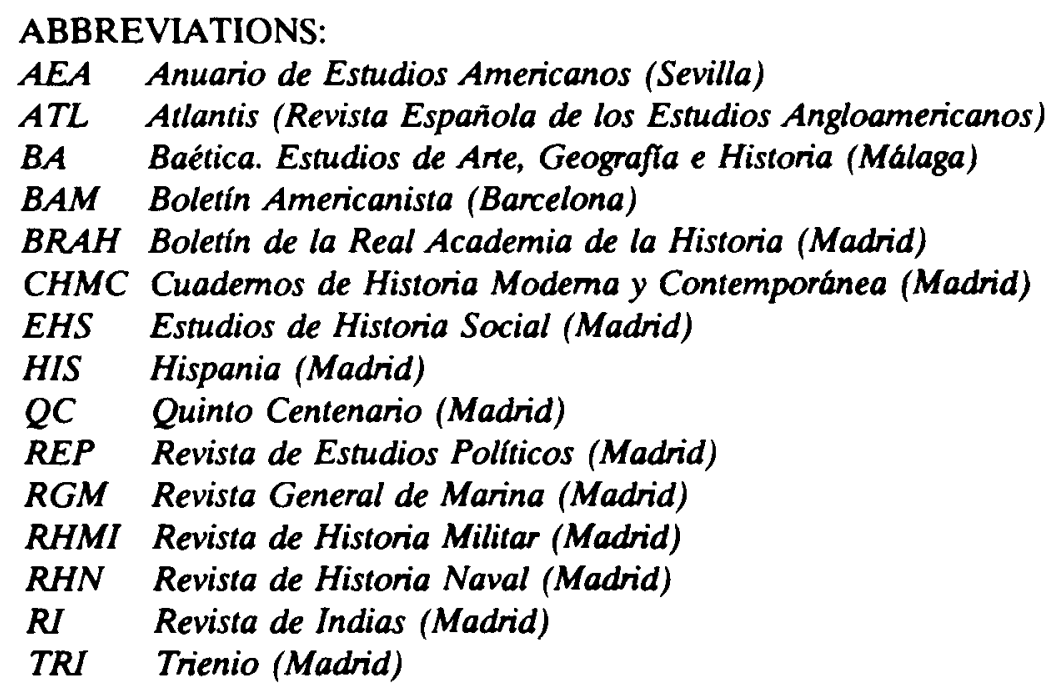

